\title{
ANALYSIS OF OFFSHORE WIND FLOW: LARGE-EDDY SIMULATION AND SEA OBSERVATIONAL DATA
}

\author{
Silvana Maldaner ${ }^{1, *}$, Umberto Rizza $^{2}$, Gervásio Annes Degrazia ${ }^{1}$, Anna Maria \\ Sempreviva ${ }^{3,4}$, Joel Rubert ${ }^{1}$, Mario Marcello Miglietta ${ }^{2}$ \\ ${ }^{1}$ Departamento de Física, Universidade Federal de Santa Maria, RS-Brasil \\ ${ }^{2}$ Institute of Atmospheric Sciences and Climate (ISAC) of the Italian National Research Council (CNR), Unit \\ of Lecce, Italy \\ ${ }^{3}$ Institute of Atmospheric Sciences and Climate (ISAC) of the Italian National Research Council (CNR), Unit \\ of Lamezia, Italy \\ ${ }^{4}$ Danish Technical University, Wind Energy Department - Roskilde Denmark \\ *silvana.maldaner@gmail.com
}

RESUMO

Neste trabalho investiga-se a camada limite atmosférica marinha diurna empregando a simulação dos grandes turbilhões (LES) e observações atmosféricas do Ligurian Air-Sea Interaction Experiment (LASIE). O código LES utilizado neste trabalho foi modificado para descrever a evolução da camada limite sobe o mar. Os resultados da análise mostram que o modelo LES realístico é adequado para simular a camada limite atmosférica marinha.

\section{INTRODUCTION}

The studies involving flow in offshore wind conditions increased in recent years. This interest is directly associated with the production of wind energy. Initially, wind farms were installed over continents, most recently over the sea. Thus, when the wind is "captured" on the sea it is called offshore wind (the wind direction is from land to sea) and this is the physical situation of the present study. Sea winds are more constant resulting in significantly higher wind energy production per wind turbine (Cañadillas et al., 2010). Therefore, one of the ways to optimize the production of energy is knowing the physics of flow under offshore conditions. 
Thereby, due to limited knowledge of the flow properties over sea, the Marine Boundary Layer is simulated employing Large Eddy Simulation.

\section{LES SIMULATION DESCRIPTION}

The LES code is modified to describe the Marine Atmospheric Boundary Layer (MABL). The force restore simplified methodology of Conzemius and Fedorovich (2010) is employed to improve the prediction of the wind, temperature and humidity profiles. In the force restore the experimental soundings of Ligurian Air-Sea Interaction experiment - LASIE 2007 were employed. The LASIE experiment was conducted by NATO (NURC NATO Undersea Research center) in the Mediterranean sea during seven days, in the summer of July 2007. In this work, the day July 20th was chosen because the sky was clear and the sea was calm (Sempreviva et al., 2010). Additionally, we use the Charnock's equation to characterize the sea surface roughness.

\subsection{NUMERICAL EXPERIMENT AND LES RESULTS}

In the numerical simulation a $(2,2,2) \mathrm{km}$ box domain with 256 points in each direction $(x, y, z)$ has been used. In the simulation the experimental surface kinematic turbulent heat flux (variable) was used as initial forcing. LASIE experimental measures of wind speed, humidity and temperature were used to initialize LES model. The simulation results for the day July 20, 2013 (16 UTC) are show in Figure 1. Figure 1 exhibits (left to right) the wind, temperature and mixing ratio profiles. The open circles represent the LASIE data and the continuous line are the LES simulation results. It is possible to observe a good agreement between LES and experimental data.

\section{CONCLUSIONS}


In this work a simulation of the Marine Boundary Layer for an offshore wind condition was performed. The force restore methodology and a characterization of the sea surface were used in the LES model. The results show a good agreement between LES profiles and LASIE experimental soundings. Therfore, the realistic LES model is suitable to simulate the MABL.

\section{ACKNOWLEDGMENTS}

This work has been supported by Brazilian Research Agencies: CAPES, CNPq and FAPERGS.

\section{REFERENCES}

CANAAILLAS, B., NEUMANN, T., RAASCH S. Getting a better understanding of the offshore marine boundary layer: Comparison between Large Eddy Simulation and offshore measurement data with focus on wind energy application. The Fifth International Symposium on Computational Wind Engineering (CWE2010) Chapel Hill, North Carolina, USA May 2327, 2010.

CHARNOCK, H. Wind stress on a water surface. Quarterly Journal of the Royal Meteorological Society 81, 639-640, 1955.

CONZEMIUS,R.J., FEDOROVICH, E. Large Eddy Simulation of Realistic Wind Fields in Daytime Atmospheric Boundary Layer. he Fifth International Symposium on Computational Wind Engineering (CWE2010) Chapel Hill, North Carolina, USA May 23-27, 2010.

DEARDORFF, J. W., Efficient prediction of ground surface temperature and moisture, with inclusion of a layer of vegetation. Journal of Geophysical Research: Oceans 83, 2156-2202, 1978. 
SEMPREVIVA, A. M., SCHIANO, M. E., PENSIERI, S., SEMEDO, A., TOMÉ, R., BOZZANO, R. ,BORGHINI, M., GRASSO, F., SOERENSEN, L. L., TEIXEIRA, J., TRANSERICI, C. Observed development of the vertical structure of the marine boundary layer during the LASIE experiment in the Ligurian Sea. Annales Geophysicae 28, 17-25, 2010.
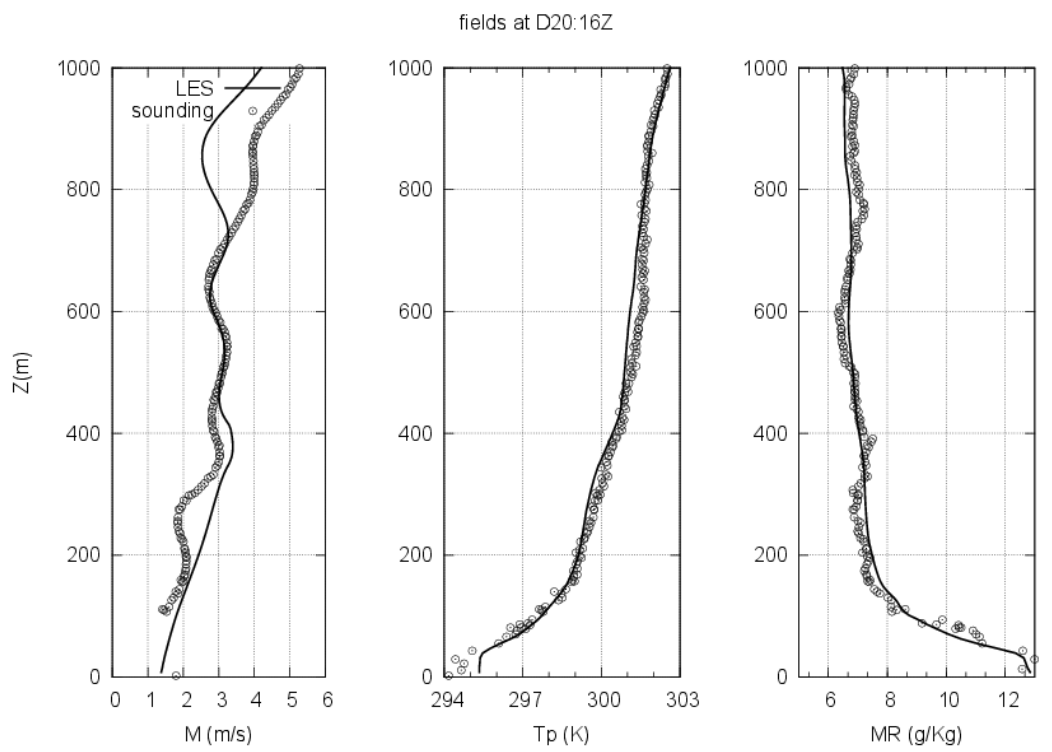

Figure 1. LES simulation and atmospheric soundings. 